\title{
Effects of N-Benzyl -9-(2-tetrahydropyranyl and Indole -3-Acetic Acid In Vitro Culture of Bauhinia purpurea $\mathrm{L}$.
}

\author{
Belai Meeta Suwal Singh \\ Department of Botany, Patan Multiple Campus, Patan Lalitpur, Nepal
}

\begin{abstract}
Bauhinia purpurea L. is a leguminous plant moderate sized tree with multipurpose value. It is distributed in sub-Himalayan tracts. It has been cultivated in the plain region up to the elevation of $1350 \mathrm{~m}$. Mature seeds of Bauhinia purpurea L. were cultured on half strength Murashige and Skoog (1962) (MS) medium. Nodal explants obtained from germinated seedlings were cultured on MS medium containing $0.5 \mu \mathrm{M}$ BAP produced multiple shoots which were used for experimental purposes. Nodal explants obtained from cultured were subcultured on different concentrations of N-Benzyl -9-(2-tetrahydropyranyl) (BPA) and Indole-3-acetic acid (IAA). The best proliferation of nodes and shoots were observed on the MS medium supplemented with $0.5 \mu \mathrm{M}$ BPA and 0.1 $\mu \mathrm{M}$ IAA. After 8 weeks of culture, the propagated plants were acclimatized and transferred to the sand box containing 1:1 soil and sand. Well rooted plants were then established in the field. All the data collected were worked out statistically with SPSS, a system of analytical procedure.
\end{abstract}

Keywords : Murashige and Skoog Medium, micropropagation, nodal explants, sand rooting, acclimatization.

\section{INTRODUCTION}

Bauhinia purpurea L. is a leguminous plant of moderate sized possessing ornamental and fodder value. It is distributed in sub-Himalayan tracts. It has been cultivated in the plain region up to the elevation of $1350 \mathrm{~m}$. The tree also yields gum and the ethnobotanical reports made by Manadhar (2000) showed that fruits are cooked and use also pickle. The wood is used for agricultural implements and is suitable for scanting and rafters in inferior construction work. The long flat pods are best until February or March. Pettit et al. (2006) have isolated new and very remarkable (dibenzan $L \mathrm{~b}$, floxipens) cancer cell growth inhibitors and have designated them as Bauhiniastatins 1-4. Upon evaluation of anticancer activity Bauhiniastatins 1 exhibited significant growth inhibition of P 388 cancer cell line.
Micropropagation of Bauhinia purpurea L. has successfully been developed by Kumar (1992) using Murashige and Skoog (1962) (MS) medium with 5.0 $\mu \mathrm{M}$ kinetin. Similarly, in vitro regeneration of Bauhinia vahlii has been developed by Dhar and Upreti (1999) using MS medium supplemented with $2.5 \mu \mathrm{M}$ kinetin plus $100 \mathrm{mg} / \mathrm{l}$ adenine sulphate. Murthur and Mukunthakumar (1992) developed in vitro propagation protocols for two leguminous trees, Bauhinia variegate and Parkinsonia aculeata from nodal explants of mature tree using MS medium with 13.3 $\mu \mathrm{M}$ and 8,9 $\mu \mathrm{M}$ BAP respectively. Here, the experiments are mainly aimed for protocol development by using BPA and IAA and establishment of plants. 


\section{MATERIAL AND METHOD}

The seeds of $B$. purpurea L. were procured from district Aforestation Division Hattisar, Kathmandu, Nepal and were carried to the Institute of Pharmacognosy, Vienna, Austria and were preserved at $4^{\circ} \mathrm{C}$ refrigerator until experimental use. The healthy seeds were washed with few drops of Teepol detergent solution. They were soaked in distilled water for an hour prior to sterilization. The soaked seeds were washed with distilled water for 5 times and sterilized with $10 \%$ sodium hypochlorite solution for 10 minutes and removed the traces of sodium hypoclorite by washing thoroughly with sterilized distilled water five times inside Laminar flow hood chamber. Finally, the seeds were again sterilized in $70 \%$ alcohol for one minute and washed with sterilized distilled water for 5 times to remove the alcohol. The seeds were inoculated on $8 \%$ (bacteriological) agar medium containing $3 \%$ sucrose and the $\mathrm{pH}$ was adjusted to 5.8 before autoclaving and then sterilized at $15 \mathrm{lb}$. / sq. inch pressure for 15 minutes in autoclave. Cultures were maintained in the culture room at $25^{\circ} \mathrm{C}\left( \pm 2^{\circ} \mathrm{C}\right)$. Cool white fluorescent light of an intensity of approx. $40 \mu$ mol.m- ${ }^{2} s^{1}$ was supplied through OSRAM BIOLUX tubes at a $16 \mathrm{hr}$ light period. Nodal explants obtained from germinated seedlings were cultured on MS medium containing $0.5 \mu \mathrm{M}$ BAP produced multiple shoots which were used for experimental purposes.

The nodal explants obtained from MS medium 0.5 $\mu \mathrm{M}$ BAP were cut into $2 \mathrm{~cm}$ pieces and were placed on MS medium supplemented with different concentrations i.e. 0.5, 1.0, 2.0 and 5.0 BPA each with $0.1,0.5,1.0$, and 2.0 IAA respectively in baby food jar $200 \mathrm{ml}$ capacity with $40 \mathrm{ml}$ medium. In each of the vessel 4 explants were inoculated. All the results obtained were worked out statistically with SPSS, a system of analytical procedure.

\section{RESULTS}

The results were taken only after 8 weeks of culture. MS medium supplemented with BPA exhibited good initiation of nodes as well as shoots. The response of proliferations on MS medium supplemented with 0.5, $0.1,2.0$ and $5.0 \mu \mathrm{M}$ BPA each with $0.1 \mu \mathrm{M}$ IAA showed good results showing 6.25 to 6.50 node numbers and 41.80 to 54.70 shoot length and 9.05 to $12.05 \phi$ calli were recorded. The response of proliferations on MS medium supplemented with 0.5, $0.1,2.0$ and $5.0 \mu \mathrm{M}$ BPA each with $0.5 \mu \mathrm{M}$ IAA showed moderate results showing 4.50 to 6.00 node numbers and 36.10 to 39.95 shoot length and 8.90 to $11.30 \phi$ calli were recorded. Similarly, on MS medium supplemented with $0.5,0.1,2.0$ and $5.0 \mu \mathrm{M}$ BPA each with $1.0 \mu \mathrm{M}$ IAA showed optimum results showing 4.10 to 6.60 node numbers and 30.80 to 51.55 shoot length and 9.00 to $11.00 \phi$ calli were recorded. In the same way, on MS medium supplemented with $0.5,0.1,2.0$ and $5.0 \mu \mathrm{M}$ BPA each with $2.0 \mu \mathrm{M}$ IAA showed minimum proliferations showing 3.75 to 5.40 node numbers and 28.75 to 41.45 shoot length and 9.05 to $10.00 \phi$ calli were recorded. A best nodes multiplication and shoots elongation were observed on the medium supplemented with $0.5 \mu \mathrm{M}$ BPA and $0.1 \mu \mathrm{M}$ IAA, where 6.50 nodes and $54.70 \mathrm{~mm}$ shoot length were recorded and the formation of calli were few i.e. 9.35 (Q) $\mathrm{mm}$ (Fig. 1) as compared to control medium (Table 1). 
Table-1: Effects of various concentrations of BPA and IAA in Bauhinia purpurea L.

\begin{tabular}{|c|c|c|c|c|}
\hline \multicolumn{2}{|c|}{$\begin{array}{l}\text { Additive/s in Media } \\
\qquad(\mu \mathbf{M})\end{array}$} & \multirow[t]{2}{*}{$\begin{array}{c}\text { Number of Nodes/culture } \\
\text { Mean } \pm \mathbf{S E}\end{array}$} & \multirow[t]{2}{*}{$\begin{array}{l}\text { Shoot length }(\mathrm{mm}) \\
\text { Mean } \pm \text { SE }\end{array}$} & \multirow[t]{2}{*}{$\begin{array}{l}\text { Q Calli }(\mathrm{mm}) \\
\text { Mean } \pm \mathbf{S E}\end{array}$} \\
\hline BPA & IAA & & & \\
\hline 0.5 & 0.1 & $6.50 \pm 0.4$ & $54.70 \pm 3.7$ & $9.35 \pm 0.5$ \\
\hline 1.0 & & $6.25 \pm 0.5$ & $48.90 \pm 4.9$ & $9.05 \pm 0.2$ \\
\hline 2.0 & & $6.35 \pm 0.6$ & $41.80 \pm 4.9$ & $9.75 \pm 0.2$ \\
\hline 5.0 & & $6.25 \pm 0.4$ & $45.95 \pm 3.6$ & $12.05 \pm 0.3$ \\
\hline 0.5 & 0.5 & $5.30 \pm 0.5$ & $39.50 \pm 4.8$ & $8.90 \pm 0.3$ \\
\hline 1.0 & & $5.25 \pm 0.4$ & $39.80 \pm 4.2$ & $8.75 \pm 0.3$ \\
\hline 2.0 & & $6.00 \pm 0.5$ & $39.95 \pm 4.6$ & $10.15 \pm 0.2$ \\
\hline 5.0 & & $4.50 \pm 0.3$ & $36.10 \pm 3.9$ & $11.30 \pm 0.3$ \\
\hline 0.5 & 1.0 & $4.10 \pm 0.3$ & $30.80 \pm 3.5$ & $9.00 \pm 0.3$ \\
\hline 1.0 & & $6.60 \pm 0.3$ & $51.55 \pm 4.0$ & $9.10 \pm 0.3$ \\
\hline 2.0 & & $6.10 \pm 0.4$ & $48.00 \pm 3.6$ & $9.90 \pm 0.3$ \\
\hline 5.0 & & $6.40 \pm 0.5$ & $46.85 \pm 4.1$ & $11.00 \pm 0.3$ \\
\hline 0.5 & 2.0 & $5.40 \pm 0.4$ & $41.45 \pm 4.0$ & $9.05 \pm 0.3$ \\
\hline 1.0 & & $5.35 \pm 0.5$ & $39.95 \pm 4.2$ & $9.45 \pm 0.3$ \\
\hline 2.0 & & $3.75 \pm 0.5$ & $28.75 \pm 4.7$ & $10.00 \pm 0.3$ \\
\hline 5.0 & & $4.35 \pm 0.5$ & $30.50 \pm 4.3$ & $9.90 \pm 0.4$ \\
\hline Control & & $1.90 \pm 0.3$ & $9.30 \pm 1.0$ & $0.0 \quad 0.0$ \\
\hline
\end{tabular}

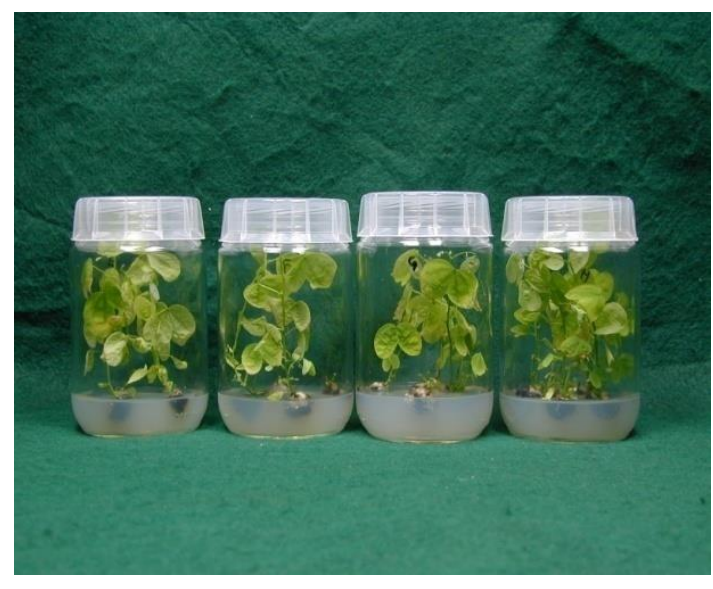

Fig. 1. Showing proliferations of shoots on MS medium with $0.5,1.0,2.0 \& 5.0 \mu \mathrm{M}$ BPA each with $0.1 \mu \mathrm{M}$ IAA from right to left respectively.

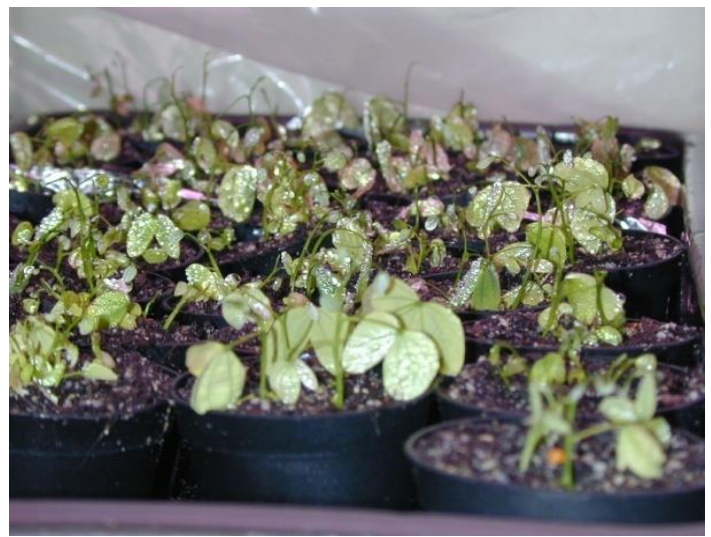

Fig. 2. Showing 3 weeks old well rooted and acclimatized plants.

For acclimatization the eight weeks old healthy plants best grown in vitro were removed from the culture and washed thoroughly in tap water to remove traces of nutrient medium and agar. The 
explants were cut with 2-3 nodes and planted on the plastic pots (diameter $6 \mathrm{~cm}$ ) which were filled with soil (Humus-Ton substrate N8) with sand in 1:1 ratio and hardened in mist chamber. The substrate was disinfected by using Benlate and Previcure. The plants were kept at high humidity (80\%) for two weeks; the humidity was reduced to $(60 \%)$ and the acclimatization process continued for two weeks. The well rooted and acclimatized plants were transferred to green house for further hardening (Fig. 2).

\section{DISCUSSIONS}

In the present work, the numbers of elongating shoots were always found higher on MS medium supplemented with $0.5 \mu \mathrm{M}$ BPA with $0.1 \mu \mathrm{M}$ IAA. The other used concentrations 1.0 $\mu \mathrm{M}$ BPA with $1.0 \mu \mathrm{M}$ IAA and $2.0 \mu \mathrm{M}$ BPA with $1.0 \mu \mathrm{M}$ IAA also produced satisfactory result. Evidently, high concentrations of both BPA and IAA suppressed the node as well as shoot formation but the formation of calli was not affected. Many researchers have worked with different auxin and cytokinin using different parts of plants. Kangilal et al. (1999) induced the production of protocorm like bodies from stem disc of Dendrobium moschatum (Buch Ham) Swartz in liquid Knundson medium supplemented with $2 \mathrm{mg} / \mathrm{l}$ NAA and $3 \mathrm{mg} / \mathrm{l}$ BAP with $15 \% \mathrm{CM}$. But Banergy et al. (1999) multiplied Centilla asiatica from leaf segments on MS medium supplemented with $2 \mathrm{mg} / 1 \mathrm{BAP}$ and $0.1 \mathrm{mg} / 1$ IBA. Similarly, Mala (2000) micropagated Wych elm (Umus glabra) smooth elm (U.minor) and European white elm (U. laevis) from buds on MS medium supplemented with $0.2 \mathrm{mg} / \mathrm{l}$ BAP, $0.1 \mathrm{mg} / \mathrm{l} \mathrm{IBA}$ and $10 \mathrm{mg} / \mathrm{l}$ glutamine. Mondol et al. (2002) propagated tea (Camellia sinensis) O. Kuntze L. from aseptic cultures of nodal segments on half strength MS medium supplemented with $8.88 \mu \mathrm{M}$ BA with $0.98 \mu \mathrm{M}$ IBA. In the same way, Hassan et al. (2010) produced shoots on Mimosa pudica L. from nodal explants on MS supplemented with 1.5 mg/l BAP 0.5 mg/l NAA. Similarly, Majumder et al. (2011) observed highest number of multiple shoots (28.1) on Scoparia dulcis L. on MS supplemented with $1.5 \mathrm{mg} / \mathrm{l} \mathrm{BAP}$ and 0.5 mg/l NAA. Amgali et al. (2016) produced higher shoot multiplication on Citrus reticulata on MS medium with $0.5 \mathrm{mg} / \mathrm{l} \mathrm{BAP}$ and $0.2 \mathrm{mg} / 1$ IAA using in vitro seedling stem as explants.

\section{v. CONCLUSION}

So, the present experiment shows that the protocol develops from the nodal explants using different combination of BPA i.e $0.5 \mu \mathrm{M}$ with IAA i.e $0.1 \mu \mathrm{M}$ are good for propagation of Bauhinia purpurea.

\section{ACKNOWLEDGEMENTS}

Prof. Dr. Brigitte Kopp and Dr. Cristoph Wawrosch of Institute of Pharmacognosy, University of Vienna and Prof. Dr. Sanu Devi Joshi, Tribhuvan University is duely acknowledged for providing the necessary supports. The Austrian Academic Exchange Service (ÖAD), Vienna Aaustria is also acknowledged for financial support.

\section{REFERENCES}

[1]. Amgali R.B., Prasai H.R. and Pandey Y.R. 2016. Hormonal effect on Mandarin orange (Citrus reticulata Blanco) micropropagation. Nepal Journal of Biotecnology. 14(1): 33-36.

[2]. Banergy S., M Zehl and S Kumar. 1999. In vitro multiplication of Centella asiatica, a medicinal 
herb from leaf explants. Current Science, 25 January 1999. 76 (2):147-148.

[3]. Dhar U. and J. Upreti. 1999. In vitro regeneration of a leguminous liana (Bauhinia vahlii Wight and Arnott). Plant Cell Reports.18: 664-669.

[4]. Hassan A.K.M.S., Sullana R., Jahan M.A.A. and Khatun R. 2010. In vitro mass propagation of Mimosa pudica L. using shoot tip and nodal explants. Bangladesh J. Sci. Ind. Res. 45(2): 95100.

[5]. Kanjilal B., D D E Sarkar, J. Mitra and K. B. Datta.1999. Stem disc culture: development of rapid masspropagation method for Dendrobium moschatum (Buch. Ham.) Swartz -an endangered orchid. Current Science, 25 August. 77(4): 497-500.

[6]. Kumar, A. 1992. Micropropagation of a mature leguminous tree- Bauhinia purpurea. Plant Cell Tissue and Organ Culture 31: 257-259.

[7]. Majumdar S., Rahman M.M. and Bhadra S.K. 2011. Micropropagation of Scoparia dulcis L.Through induction of indirect organogenesis. Asian Pacific J. Mol. Biotecnol. 19(1): 11-17.

[8]. Mala J. 2000. Micropropagation of mature elm tree in vitro. Journal of Forest Science. 46(6): 260-264.

[9]. Manandhar N.P. 2002. Plant and People of Nepal. 106.

[10]. Mathur J. and S. Mukunthakumar. 1992. Micropropagation of Bauhinia variegata and Parkinsonia aculeata from nodal explants of mature trees. Plant Cell Tissue and Organ Culture 28:119-121.

[11]. Mondal T K, A Bhattacharya, A Sood and P S Ahuja. 2002. Propagation of Tea (Camelia sinensis (L.) O. Kuntze) by shoot proliferation of alginate- encapsulated buds stored at 4 o C. Current Science, 25 October, 83(8): 941-944.
[12]. Murashige T. and F. Skoog. 1962. A revised medium for rapid growth and bioassays with tobacco tissue culture.s Physiol. Plant. 15: 473497.

[13]. Pettit G. R. Numata A. Jwamoto C., Usami M. Yamada T. Oshishi H. and Cragy G. M. 2006. Antineoplastic Agents, Isolation and structure of Bauhinastatins 1-4 from Bauhinia purpurea. J. Nat. Prod. 69: 323-327.

\section{Cite this article as :}

Belai Meeta Suwal Singh, "Effects of N-Benzyl -9-(2tetrahydropyranyl and Indole -3-Acetic Acid In Vitro Culture of Bauhinia purpurea L.", International Journal of Scientific Research in Science and Technology (IJSRST), Online ISSN : 2395-602X, Print ISSN : 2395-6011, Volume 6 Issue 3, pp. 238-242, May-June 2019. Available at doi : https://doi.org/10.32628/IJSRST1196339 Journal URL : http://ijsrst.com/IJSRST1196339 